'rational conversion'), an analysis of Isaac Newton's rhetorical devices in early and late writings on optics, and the origins of Darwin's Origin. These draw on established historical sources, and I doubt that an historian of science, of whatever philosophical persuasion, would disagree with them. There are also essays on scientific practice which seem not to entail any radical conclusions about scientific knowledge.

But in the epilogue, on 'Reference without Reality', he picks up the theme again, and seems nearly to make scientific agreement and disagreement a matter of taste. Quoting D. Davidson, he reduces Kuhn's paradigmconflicts to how 'we' choose to phrase our differences. Similarly, he quotes N. Goodman on truth as being "like intelligence, perhaps just what the tests test." I agree with his statement (near the end) that the sciences create bodies of knowledge so persuasive as to seem unrhetorical, but to me it seems capricious to imagine this persuasion being accomplished more by rhetorical devices than by argument based ultimately (with however many lacunae and imperfections) on a controlled and shared experience of an external world.

J. R. Ravetz is at The Research Methods Consultancy Limited, Quality Assurance for Scientific Information, 13 Temple Gardens, London NW11 OLP, UK.

\section{Man of courage}

Nevill Mott

Kapitza In Cambridge and Moscow. Edited by J. W. Boag, P. E. Rubinin and D. Schoenberg. Elsevier: 1990. Pp.429. Hbk $\$ 77$, Dfl 150; pbk $\$ 38$ 50, Dfl75.

SINCE his death in 1984 parts of the story of Peter Kapitza have been told in several publications. Kapitza in Cambridge and Moscow contains his letters and has a biographical introduction in which David Schoenberg tells the story again. Born in 1884 at Kronstadt near St Petersburg, he was a student at St Petersburg Polytechnic during most of the war of 1914-1918 and married and fathered a son. But in the terrible conditions after the revolution and civil war, first his father died, then his son and finally his wife, shortly after giving birth to his daughter who died too. Naturally enough, Kapitza was slow to recover, but in 1921 Abraham Joffe, the leader of Russian physics at that time, with the support of Lenin organized a trip abroad "for renewing scientific relations with other countries." He included Kapitza in the party, who in England by sheer force of character persuaded Rutherford to take him on in the Cavendish, where he stayed for 13 years. He achieved great success in research, a fellowship of the Royal Society (though remaining a Soviet citizen) and a fellowship in Trinity College. Included in the book are translations of his letters to his mother at that time. One quotation will suffice, "Today the Crocodile [Rutherford] summoned me twice to discuss my paper. It will be published in the Proceedings of the Royal Society, which is the greatest honour a piece of research can achieve here. It is only now that I have felt my strength. Success gives me wings and I am carried along by my work." Also, he married again.

I knew Kapitza well at that time. In 1934 we both went to the Soviet Union, as he often did. For me the occasion was a conference to celebrate the hundredth anniversary of the birth of Mendeliev. Kapitza had omitted to obtain an assurance from the Soviet embassy that he could return to England, and found that he could not. Letters to Rutherford, and to his wife, Anna, who remained in England for two years, form a major part of the book. At first he was miserable. Colleagues, not knowing if he was in favour or not, shunned him. But later his situation improved, and he showed his sincere belief in the socialist creed, and his desire to help the explosive growth of science in the socialist motherland.

Perhaps most interesting are the 'Letters to the Kremlin', to Molotov, Stalin, Kruschev, in which he showed amazing courage. He secured the release of L. D. Landau, Russia's most brilliant young theorist, after one year of a prison regime which could soon have killed him. He complains how hard it is to run a research institute on the basis of a detailed plan for the year ahead, so that it is impossible to obtain supplies to fill an unexpected need. He writes to Stalin that the Academy of Sciences is full of third-rate old
men and that the only way to change this is for the Soviet populace to show the same pride in their science as they do in their ballet. To Keldysh, President of their Academy of Sciences he writes as late as 1972 how intolerable it is that his travel arrangements are always interfered with, for instance that his permission to attend the Rutherford Centenary Celebrations at the Royal Society was withdrawn at the last moment because of the expulsion by Britain of members of the Soviet trades delegation.

Curiously, there are letters to Max Born after he left Germany in 1933 and to Niels Bohr after he escaped from Denmark in 1943, offering them permanent positions in Moscow. To Born he writes, "please consider our $1 / 6$ of the world as a possible place for you to settle". After describing some of the hardships, he writes, "After all, the Bolshies are angels compared to your Nazis, and what is much more they have a true case to fight for... I agree with you they are the only ones who keep the right line, and indeed a winning one."

Compared to the Nazis, yes - but in any absolute sense, could he have thought so?

There are some curious letters about a particular scheme of his for destroying missiles in flight by intense electromagnetic radiation. This was not pursued.

At the end of the war he seems to have been in charge from the scientific side of the Russian project to build an atomic bomb, and the famous letter to Stalin is reproduced, saying how impossible it was to work with

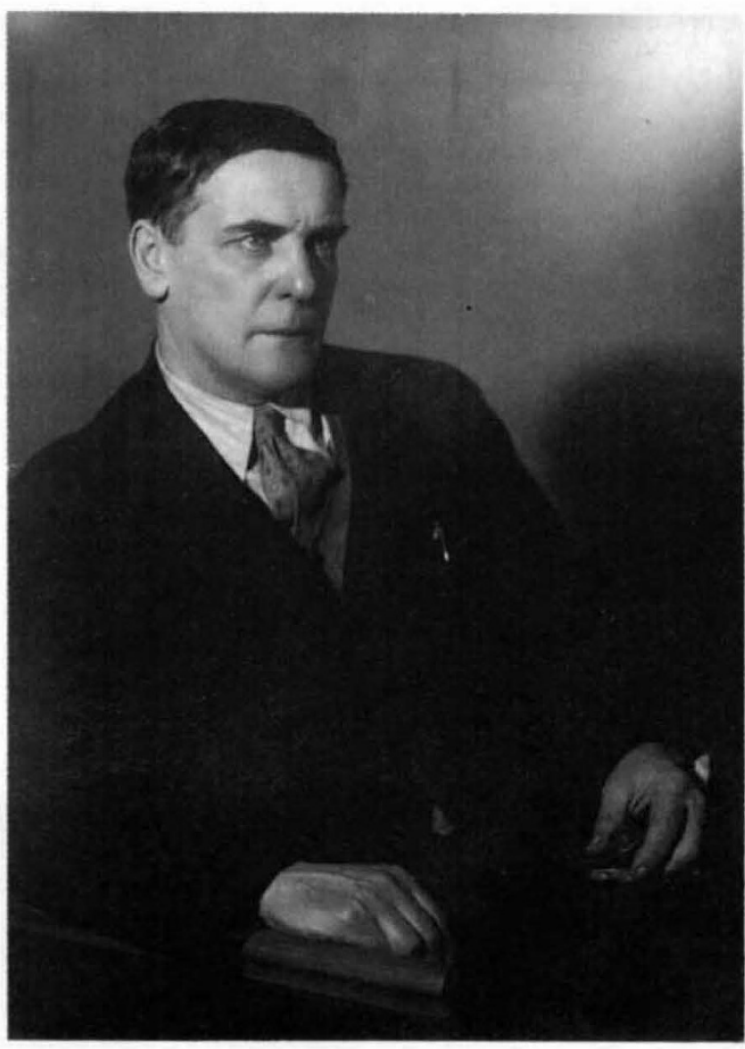

Kapitza - Fellow of the Royal Society and member of the my of Sciences.

Lavrenti Beria, who seems to have been their General Groves. "You don't understand science", says Kapitza. "You don't understand people", says Beria. After this, maybe ostensibly for other reasons, Kapitza was removed from the project, though not from his membership of the Academy with its salary. He continued to write to Stalin.

After Stalin's death and the execution of Beria, Kapitza came back into favour. The book ends with some letters to Andropov about Sakharov and Orlov, referring to Lenin's respect for scientists.

To anyone who knew him, Kapitza in Cambridge and Moscow brings back the memory of a very great man, lovable and human, and of his life under a tyranny of a kind that has not yet disappeared from the world.

Sir Nevill Mott is at 63 Mount Pleasant, Milton Keynes MK17 8JX, UK. 